\title{
Morphological traits and water use strategies in seedlings of Mediterranean coexisting species
}

\author{
E. I. Hernández $\cdot$ A. Vilagrosa • \\ J. G. Pausas · J. Bellot
}

Received: 15 April 2009/Accepted: 9 September 2009/Published online: 21 September 2009

(C) Springer Science+Business Media B.V. 2009

\begin{abstract}
The distribution of plants is associated with their different patterns of response to their environment. Mediterranean plants have evolved a number of morphological and physiological adaptations that determine their ability to survive and grow, being an effective water uptake and use important factors for drought resistance. In this article, we evaluated interspecific differences in morphology, biomass allocation, and architectural traits and their relationship with water use strategies in seedlings of seven co-occurring Mediterranean species (Anthyllis cytisoides L., Genista scorpius L. DC., Myrtus communis L., Pistacia lentiscus L., Rosmarinus officinalis L., Spartium junceum L. and Ulex parviflorus Pourr.). The results showed that morphological root features
\end{abstract}

Electronic supplementary material The online version of this article (doi:10.1007/s11258-009-9668-2) contains supplementary material, which is available to authorized users.

E. I. Hernández $(\bowtie) \cdot$ J. Bellot

Departamento de Ecología, Universidad de Alicante, Apartado de correos 99, 03080 Alicante, Spain e-mail: encarni.hernandez@ua.es

A. Vilagrosa

Fundación Centro de Estudios Ambientales del

Mediterráneo (CEAM), Charles R. Darwin 14,

Parque Tecnnológico, 46980 Paterna, Valencia, Spain

J. G. Pausas

CIDE, CSIC, Apartado Oficial, 46470 Albal, Valencia, Spain vary among species and they are significantly correlated with root hydraulic conductance and leaf gas exchange variables. Species with high specific root length (SRL) showed a low hydraulic conductance per root length $\left(K_{\mathrm{RRL}}\right)$ but high specific hydraulic conductance $\left(K_{\mathrm{As}}\right)$. M. communis and P. lentiscus showed the most contrasting water use patterns with respect to the other species studied. The results are not affected when considering phylogenetic relatedness. Thus, the variability observed in root hydraulic properties and leaf gas exchange suggests important mechanisms for understanding species coexistence in water-limited ecosystems.

Keywords Hydraulic conductance .

Leaf gas exchange $\cdot$ Mediterranean species .

Root morphology

\section{Introduction}

Summer droughts and wildfires are two main ecological factors shaping Mediterranean ecosystems (Specht 1987; Pausas 2004). Species composition of the mature vegetation is determined through the differential survival and growth patterns exhibited by seedlings (Levin and Schmidt 1985; Pratt et al. 2007). Seedling emergence and survival are crucial events in the life cycle of plants, being decisive for their performance and success in water-limited environments (Pausas et al. 2004; Ojeda et al. 2005). 
Different species survive and coexist by means of a diversity of functional strategies (Vilagrosa et al. 2003; Paula and Pausas 2006; Galmés et al. 2007). However, the patterns and processes underlying this phenomenon are still not fully understood (Keeley et al. 2005; Pratt et al. 2007).

Different species ability to respond to changes in water availability has been associated with morphological and physiological traits and constraints (Keeley 1998; Mitchell et al. 2008). In this context, droughtresistant plant traits have been synthesized in several functional classifications, on the basis of leaf habit (Clemente et al. 2005; Jacobsen et al. 2007a), rooting structure (Kummerow 1981; Canadell and Zedler 1995; Jacobsen et al. 2007a), regeneration strategy (Paula and Pausas 2006) or hydraulic architecture and drought resistance strategy (Levitt 1980; Tyree et al. 1994; Valladares et al. 2008).

Morphological and physiological features and responses to water conditions are not independent but related (Ackerly 2004; Lambers et al. 2006). Species show different aboveground and belowground characteristics responsible for their survival, growth, and reproduction in different habitats. There is broad evidence supporting a correspondence between the various root system traits developed by species in drought-prone ecosystems and their performance (Davis et al. 1999; Bell 2001; Verdaguer and Ojeda 2002), with important implications on the extent of fluctuations in water status of species (Fleck et al. 1995, 1998). In addition, it has been reported that the first summer rainless period after seedling establishment is a major limiting factor when seedling roots are not fully developed (Vallejo et al. 1999; Pratt et al. 2007).

Roots impose the greatest resistance to liquid water flow in the soil-plant-atmosphere continuum (Sperry et al. 2002); thus, effective water uptake is an important factor in species performance (Rieger and Litvin 1999). The capacity for water transport from soil to leaves is highly dependent on root architecture (Addington et al. 2006; Chirino et al. 2008), which is important in both determining how plants respond to water availability and in setting maximum rates of gas exchange (Brodribb and Feild 2000; Hubbard et al. 2001).

On the other hand, the physiological basis for the regulation of water use efficiency at leaf level is not fully clear because it depends on complex arrangements and interactions of physiological mechanisms and plant architecture (Pou et al. 2008). In this regard, specific differences in water use strategies can determine the capacity to survive under situations of water deficit (Martínez-Vilalta et al. 2002; Vilagrosa et al. 2003). Species can display water-saving mechanisms in order to prevent water deficit damage, decreasing water loss by closing their stomata or regulating the water flow to leaves by low root hydraulic conductance. In contrast, water-spending species increase their root hydraulic conductance, thus increasing water absorption, which allows them to extract water from soil to support high leaf gas exchange rates (Levitt 1980; Lo Gullo and Salleo 1988) even if their stomatal behavior involves xylem cavitation and consequently loss of hydraulic conductance (Nardini and Salleo 2000). In addition, it has been reported that variations in water use efficiency at leaf-level are closely related to variations in hydraulic conductance showed by species (Tyree et al. 1998; Pratt et al. 2007; Medrano et al. 2009). Accordingly, stomatal response can be interpreted on the basis of plant hydraulic conductance (Cochard et al. 2000; Ewers et al. 2000), and it is highly dependent on growth form and species (Ackerly 2004; Galmés et al. 2007).

The aim of the present study was to better understand the diversity of morphological traits and water use strategies in coexisting Mediterranean species. We undertook a comparative nursery experiment with seven coexisting Mediterranean shrubs that encompass the range of dominant strategies in the study area (i.e., different leaf and stem habit, and different post-fire strategy). We hypothesized that coexisting species diverge in their set of traits related to water use strategies, and that root system traits determine different water use strategies (Huang and Eissenstat 2000; Pemán et al. 2006). We examined allocation to aboveground and belowground tissues, root system morphology and water-relation traits. The link between morphological and functional responses evaluated in these species was expected to reveal the diversity of adaptive mechanisms among coexisting species.

\section{Materials and methods}

Study species

The species were selected for their abundance and coexistence in Eastern Iberian Peninsula thermo- 
mediterranean ecosystems, with a mean annual rainfall of 250-600 $\mathrm{mm}$. The species included were: Anthyllis cytisoides L., Genista scorpius L. DC., Myrtus communis L., Pistacia lentiscus L., Rosmarinus officinalis L, Spartium junceum L., and Ulex parviflorus Pourr. (Table 1).

Seeds of these species were collected in the field from local provenance and placed in Petri dishes at $18^{\circ} \mathrm{C}$ in darkness in a germination chamber. After the germination and emergence of one true leaf, seedlings were individually transplanted into pots (201 in volume, $40 \mathrm{~cm}$ in height) containing sandy loam soil (USDA soil texture classification) and grown in a nursery $\left(39^{\circ} 28^{\prime} \mathrm{N} 0^{\circ} 31^{\prime} \mathrm{W}\right.$; Banc de Llavors, Generalitat Valenciana, Valencia, Spain). Seedlings of each species were randomly distributed under a light reduction mesh with an $80 \%$ transmittance of full sunlight. The experiment was performed on late spring-summer in 2005; the maximum average temperature during the experiment was registered in July $\left(25.0^{\circ} \mathrm{C}\right)$ and the minimum in May $\left(18.7^{\circ} \mathrm{C}\right)$. Mean irradiance during the experiment was $23.76 \mathrm{MJ} \mathrm{m}^{-2}$ day $^{-1}$ and the mean monthly relative humidity of the air was $64.9 \%$ (Valencia weather station). The pots were equally well watered 3 days per week and plants were maintained at field capacity before the measurements. A sample of 4-6 seedlings from each species (a total of 38 seedlings) was selected to perform all subsequent measurements (gas exchange, hydraulic conductance, and morphological characterization). Plant age when measurements were taken depended on species phenology: G. scorpius, $S$. junceum, and $U$. parviflorus plants were 4 months old, while A. cytisoides, $P$. lentiscus, $M$. communis, and $R$. officinalis plants were 3 months old; however, all plants were phenologically similar and with similar sizes (basal diameter between 4 and $6 \mathrm{~mm}$ ).

\section{Morphological measurements}

Stems, leaves, and roots of each seedling were separated. Root surface area $\left(A_{\mathrm{R}}, \mathrm{m}^{2}\right)$, root length (RL, m) and photosynthetic area $\left(A_{\mathrm{P}}, \mathrm{m}^{2}\right)$ were measured by scanning the material and analyzing the images with a specific software (WinRhizo, Régent Instruments Inc., Quebec, Canada). G. scorpius, S. junceum, and $U$. parviflorus have small leaves and green photosynthetic stems, and thus both leaf and stems areas were considered to determine $A_{\mathrm{P}}$.

Sapwood area $\left(A_{\mathrm{S}}, \mathrm{cm}^{2}\right)$ was calculated using the stems collected for measurements of hydraulic conductance. Stem cross-section was measured after the bark was removed at the root collar level and under the assumption that all xylem was sapwood. Crosssectional area was calculated considering diameters in two perpendicular directions. The samples were weighed after drying in a forced-air oven at $65^{\circ} \mathrm{C}$ up to constant weight. The biomass allocation variables considered were: aboveground (AMF, $\mathrm{g} \mathrm{g}^{-1}$ ), root (RMF, $\left.\mathrm{g} \mathrm{g}^{-1}\right)$, stem (SMF, $\mathrm{g} \mathrm{g}^{-1}$ ) and leaf mass fraction (LMF, $\left.\mathrm{g} \mathrm{g}^{-1}\right)$, as well as the root to shoot ratio $\left(\mathrm{g} \mathrm{g}^{-1}\right)$. Specific root length (i.e., the root length per unit of root mass, SRL, $\mathrm{m} \mathrm{g}^{-1}$ ) and the ratio root length to total plant biomass $\left(\mathrm{RL} / \mathrm{B}, \mathrm{m} \mathrm{g}^{-1}\right.$ ) were also measured. Leaf mass per area (LMA, $\mathrm{g} \mathrm{m}^{-2}$ ) was calculated in four expanded leaves from different individuals per species as the ratio of leaf dry mass to leaf area. Sapwood area per photosynthetic area

Table 1 List of the species included in this study, their family, code used, and brief description, including post-fire regeneration strategy

\begin{tabular}{llll}
\hline Species & Family & Species code & Description \\
\hline Anthyllis cytisoides L. & Fabaceae & Acy & Semi-deciduous shrub, facultative \\
Genista scorpius L. & Fabaceae & $\mathrm{Gsc}$ & Green-stemmed shrub, facultative \\
Spartium junceum L. & Fabaceae & $\mathrm{Sju}$ & Green-stemmed shrub, facultative \\
Myrtus communis L. & Myrtaceae & Mco & Broad-leaved evergreen shrub, resprouter \\
Pistacia lentiscus L. & Anacardiaceae & Ple & Broad-leaved evergreen shrub, resprouter \\
Rosmarinus officinalis L. & Labiatae & Rof & Narrow-leaved evergreen shrub, seeder \\
Ulex parviflorus Pourr. & Fabaceae & Upa & Green-stemmed shrub, seeder \\
\hline
\end{tabular}

Species with green stems have very few and small leaves 
$\left(A_{\mathrm{S}}: A_{\mathrm{P}}, \mathrm{cm}^{2} \mathrm{~m}^{-2}\right)$ and root-to-photosynthetic area ratio $\left(A_{\mathrm{R}}: A_{\mathrm{P}}, \mathrm{m}^{2} \mathrm{~m}^{-2}\right)$ were also calculated.

Gas exchange and root hydraulic conductance measurements

We measured gas exchange and hydraulic conductance parameters in each seedling prior to taking the above measurements on morphological traits. In each seedling we measured: instantaneous determinations of net $\mathrm{CO}_{2}$ assimilation ( $A$, $\mu \mathrm{mol} \mathrm{CO}_{2} \mathrm{~m}^{-2} \mathrm{~s}^{-1}$ ), stomatal conductance $\left(g_{\mathrm{s}}, \mathrm{mol} \mathrm{H}_{2} \mathrm{O} \mathrm{m} \mathrm{m}^{-2} \mathrm{~s}^{-1}\right)$, and intrinsic water use efficiency (WUEi, $\mu \mathrm{mol} \mathrm{CO}_{2} / \mathrm{mol}$ $\left.\mathrm{H}_{2} \mathrm{O}\right)$ as the ratio of $A / g_{\mathrm{s}}$ at saturating light $\left(1,500 \mu \mathrm{mol}\right.$ photon $\left.\mathrm{m}^{-2} \mathrm{~s}^{-1}\right), 25^{\circ} \mathrm{C}$, and $380 \mu \mathrm{mol}-$ $\mathrm{mol}^{-1} \mathrm{CO}_{2}$. All these measurements were performed at mid-morning with a portable photosynthesis opensystem (Model LI-6400, LI-COR Inc., Nebraska, USA), maintaining the relative humidity in the chamber at $55 \pm 5 \%$. Air temperature and humidity measurements were performed to ensure that the conditions inside the chamber were similar. The gas exchange data were recorded after equilibration to steady state when coefficient of variation was $\leq 3 \%$ (around $10 \mathrm{~min}$ ). In G. scorpius, S. junceum and U. parviflorus species portions of stems with a varying number of leaves were placed in the chamber. Leaf and stem areas were then determined to scale gas exchange measurements per unit of total photosynthetic area.

Hydraulic conductance was measured on the whole root system of each seedling using a high pressure flow meter (HPFM, Dynamax, Houston, USA), as described in Tyree et al. (1995). Shoots were cut under water at the root collar level. Root systems were kept in their substrate and after connect to the HPFM were perfused with distilled and degassed ultra-pure water filtered through a $0.1 \mu \mathrm{m}$ water filtration membrane. Root hydraulic conductance $\left(K_{\mathrm{R}}\right.$, mol $\left.\mathrm{MPa}^{-1} \mathrm{~s}^{-1}\right)$ was calculated from transient measurements as: $K_{\mathrm{R}}=F / \Delta P$, where $F$ is the measured flow and $\Delta P$ was the applied pressure every few seconds. The slope of the relationship between $F$ and $\Delta P$ was taken as $K_{\mathrm{R}} . K_{\mathrm{R}}$ was corrected for water temperature and then scaled on a root length basis $\left(K_{\mathrm{RRL}}, \mathrm{mol} \mathrm{m}^{-1} \mathrm{~s}^{-1} \mathrm{MPa}^{-1}\right)$ and stem crosssection area $\left(K_{\mathrm{As}}, \mathrm{mol} \mathrm{m}^{-2} \mathrm{~s}^{-1} \mathrm{MPa}^{-1}\right) . K_{\mathrm{As}}$ is a measure of the potential of the root system to supply water to the aboveground part of the plant.
Statistical analysis

Differences among species were analyzed using ANOVA. Species pairwise comparisons were performed with Tukey post hoc tests at the $P<0.05$ significance level. The relationships between the studied variables were analyzed using the Pearson correlations in cross-species analysis. In order to verify to what extend the results are due to phylogenetic relatedness among species, the correlation between variables was also performed using phylogenetic independent contrasts (PICs; Felsenstein 1985). A phylogenetic tree was assembled based on the supertree available in the "Phylocom" software (Webb et al. 2008) and considering the phylogeny of Fabaceae (Pardo et al. 2004). To better understand the multidimensional strategy of the coexisting species, a principal components analysis (PCA) was conducted with all measured morphological and functional variables, using mean values of the variables for each species.

\section{Results}

Morphological measurements

The species studied showed different patterns of biomass allocation (Table 2). M. communis and $P$. lentiscus were the species with the highest allocation to roots (RMF), while the green-stemmed species ( $G$. scorpius, $S$. junceum, and $U$. parviflorus) showed the highest allocation to stems (SMF) and the lowest to leaves (LMF). Root to shoot ratio ranged from 0.17 in $U$. parviflorus to $0.51 \mathrm{~g} \mathrm{~g}^{-1}$ in $M$. communis. The structure of the root systems also differed among the species. R. officinalis, P. lentiscus and S. junceum showed the highest specific root length (SRL), and this result was corresponded with the highest values of root length to total plant biomass (RL/B). $M$. communis was the species that showed the lowest SRL and RL/B, while P. lentiscus and $R$. officinalis displayed the highest RL/B values (Table 2).

A highly significant positive correlation was found between RL/B and SRL through the seven species studied for both cross-species analysis and PICs (Fig. 1; Table 3). LMA and the root-to-photosynthetic area ratio $\left(A_{\mathrm{R}}: A_{\mathrm{P}}\right)$ showed significant differences among species. G. scorpius and $R$. officinalis 


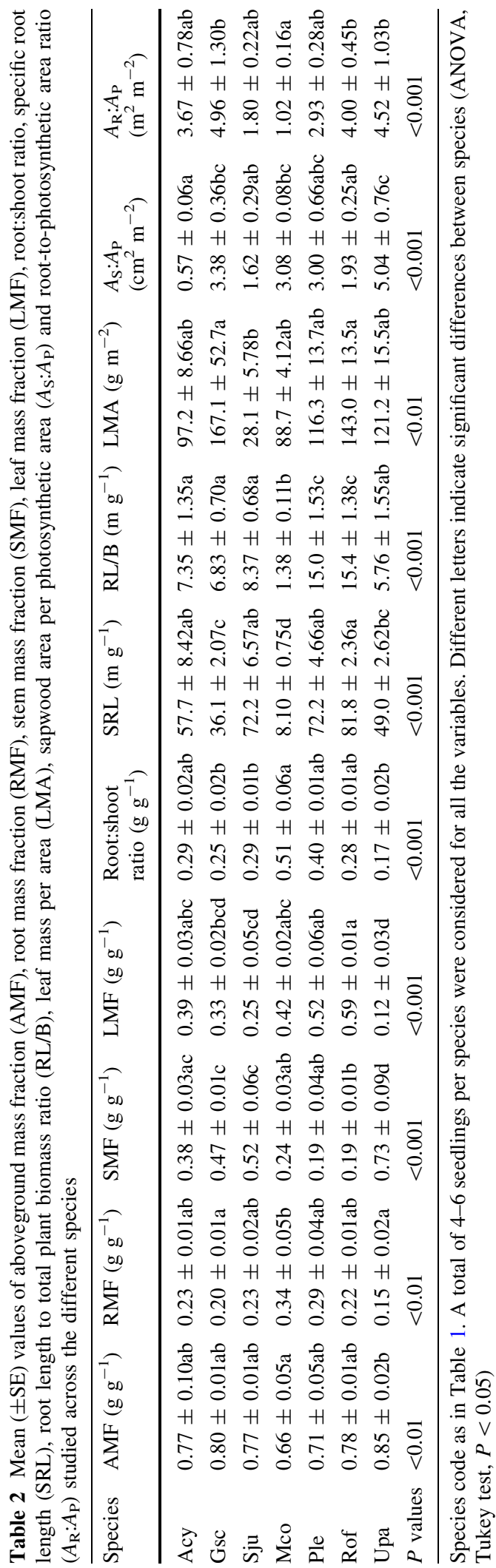

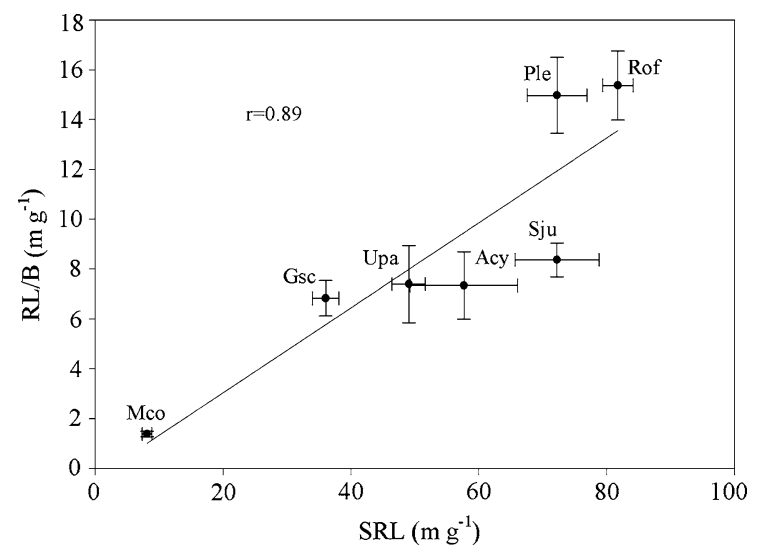

Fig. 1 Relationship between root length to total plant biomass ratio (RL/B, $\mathrm{m} \mathrm{g}^{-1}$ ) and specific root length (SRL, $\mathrm{m} \mathrm{g}^{-1}$ ) for the seven species studied. Each value represents the mean. Bars indicate \pm SE $(n=4-6)$. Species code as in Table 1. Cross-species and PIC correlations are shown in Table 3

showed significantly highest LMA compared with $S$. junceum, while G. scorpius, $R$. officinalis and $U$. parviflorus showed the highest $A_{\mathrm{R}}: A_{\mathrm{P}}$, differing significantly from $M$. communis. $U$. parviflorus showed a high sapwood area per photosynthetic area $\left(A_{\mathrm{S}}: A_{\mathrm{P}}\right)$ respect to the rest of the species (Table 2).

Gas exchange and root hydraulic conductance

Significant differences were found among the species with respect to the physiological variables studied (Table 4). The highest leaf photosynthesis $(A)$ was found in P. lentiscus, followed by A. cytisoides and $R$. officinalis. $M$. communis was the species that presented both the lowest $A$ and stomatal conductance $\left(g_{\mathrm{s}}\right)$. However, M. communis showed the highest intrinsic water use efficiency (WUEi). Root hydraulic conductance in a root length basis $\left(K_{\mathrm{RRL}}\right)$ and specific root hydraulic conductance $\left(K_{\mathrm{As}}\right)$ also showed significant differences among the species. $M$. communis was the species with the lowest $K_{\text {As }}$, differing significantly from $P$. lentiscus which showed the highest value. Nevertheless, M. communis and $G$. scorpius were the species that exhibited the highest $K_{\mathrm{RRL}}$ value (Table 4).

$A$ was positively correlated with $K_{\mathrm{As}}$ for crossspecies and a marginally significant correlation for PICs; however, a negative significant correlation was found between $A$ and $K_{\mathrm{RRL}}$ for both cross-species and PICs across species (Fig. 2; Table 3). Physiological traits were found to be correlated with the 
Table 3 Correlation coefficients $(r)$ and the $P$ values of the statistical comparison according to cross-species analysis and phylogenetic independent contrasts (PICs) between selected variables discussed in the text: net $\mathrm{CO}_{2}$ assimilation $(A)$, stomatal conductance $\left(g_{\mathrm{s}}\right)$, specific root hydraulic conductance $\left(K_{\mathrm{As}}\right)$, root hydraulic conductance per root length $\left(K_{\mathrm{RRL}}\right)$, specific root length (SRL) and root length to total plant biomass ratio $(\mathrm{RL} / \mathrm{B})$

\begin{tabular}{|c|c|c|c|c|}
\hline \multirow[t]{2}{*}{ Traits } & \multicolumn{2}{|c|}{ Cross-species correlations } & \multicolumn{2}{|c|}{ PIC correlations } \\
\hline & $r$ & $P$ values & $r$ & $P$ values \\
\hline \multicolumn{5}{|l|}{$A$} \\
\hline$K_{\mathrm{As}}$ & 0.87 & 0.010 & 0.73 & 0.060 \\
\hline$K_{\mathrm{RRL}}$ & -0.73 & 0.063 & -0.44 & 0.326 \\
\hline SRL & 0.81 & 0.029 & 0.64 & 0.120 \\
\hline RL/B & 0.86 & 0.013 & 0.82 & 0.023 \\
\hline \multicolumn{5}{|l|}{$g_{\mathrm{s}}$} \\
\hline$K_{\mathrm{As}}$ & 0.85 & 0.016 & 0.78 & 0.037 \\
\hline$K_{\mathrm{RRL}}$ & -0.66 & 0.108 & -0.48 & 0.272 \\
\hline SRL & 0.63 & 0.131 & 0.57 & 0.178 \\
\hline RL/B & 0.59 & 0.159 & 0.64 & 0.122 \\
\hline \multicolumn{5}{|l|}{ SRL } \\
\hline$K_{\mathrm{As}}$ & 0.68 & 0.094 & 0.65 & 0.111 \\
\hline$K_{\mathrm{RRL}}$ & -0.90 & 0.006 & -0.84 & 0.018 \\
\hline RL/B & 0.89 & 0.010 & 0.82 & 0.024 \\
\hline
\end{tabular}

Italic text indicates a significant correlation $(P<0.05)$

See Electronic Supplementary Material for a full correlation matrix

morphological characteristics of the root system measured. $A$ was positively correlated with SRL for cross-species analysis and with RL/B for both crossspecies analysis and PICs. In contrast, $K_{\mathrm{RRL}}$ showed a

Table 4 Mean $( \pm \mathrm{SE})$ values for net $\mathrm{CO}_{2}$ assimilation $(A)$, stomatal conductance $\left(g_{\mathrm{s}}\right)$, intrinsic water use efficiency (WUEi), root hydraulic conductance scaled on a root length negative correlation with SRL and RL/B for both cross-species analysis and PICs (Table 3).

Multivariate analysis

Principal components analysis, computed from species' mean values of the morphological and physiological variables, resulted in two axes explaining ca. $72 \%$ of the total variance. The first axis (PC1, explaining $43.1 \%$ of the total variance) was related to physiological variables. It was positively linked to $g_{\mathrm{s}}$ (0.94), $K_{\mathrm{As}}(0.89)$, and $A(0.83)$, and negatively to WUEi (-0.84). PC1 separated the species with a higher variation in gas exchange variables and specific hydraulic conductance from the species with a high WUEi. The second axis (PC2, explaining $28.7 \%$ of the variance) separated the species in relation to root and stem biomass allocation and root hydraulic architecture traits. PC2 was positively linked to RMF (0.96) and root to shoot ratio (0.90), and negatively linked to $A_{\mathrm{R}}: A_{\mathrm{P}}(-0.90)$ and $\mathrm{SMF}$ $(-0.60)$, with $M$. communis in the positive extreme and $U$. parviflorus in the negative one (Fig. 3).

\section{Discussion}

Morphological traits among species

Morphological traits differed widely among species. We found that the two obligate resprouters $M$. communis and $P$. lentiscus showed the highest

basis $\left(K_{\mathrm{RRL}}\right)$ and specific root hydraulic conductance $\left(K_{\mathrm{As}}\right)$ studied across the different species

\begin{tabular}{llllll}
\hline Species & $\begin{array}{l}A(\mu \mathrm{mol} \\
\left.\mathrm{CO}_{2} \mathrm{~m}^{-2} \mathrm{~s}^{-1}\right)\end{array}$ & $\begin{array}{l}g_{\mathrm{s}}(\mathrm{mol} \\
\left.\mathrm{H}_{2} \mathrm{O} \mathrm{m}^{-2} \mathrm{~s}^{-1}\right)\end{array}$ & $\begin{array}{l}\text { WUEi }(\mu \mathrm{mol} \\
\left.\mathrm{CO}_{2} \mathrm{~mol}^{-1} \mathrm{H}_{2} \mathrm{O}\right)\end{array}$ & $\begin{array}{l}K_{\mathrm{RRL}}\left(\mathrm{mol} \mathrm{m}^{-1} \mathrm{~s}^{-1}\right. \\
\left.\mathrm{MPa}^{-1} \times 10^{-5}\right)\end{array}$ & $\begin{array}{l}K_{\mathrm{As}}\left(\mathrm{mol} \mathrm{m} \mathrm{m}^{-2} \mathrm{~s}^{-1}\right. \\
\left.\mathrm{MPa}^{-1} \times 10^{2}\right)\end{array}$ \\
\hline Acy & $17.8 \pm 1.48 \mathrm{ab}$ & $0.44 \pm 0.01 \mathrm{ab}$ & $40.0 \pm 2.69 \mathrm{a}$ & $0.33 \pm 0.11 \mathrm{a}$ & $0.93 \pm 0.18 \mathrm{ab}$ \\
$\mathrm{Gsc}$ & $12.6 \pm 1.19 \mathrm{bc}$ & $0.24 \pm 0.02 \mathrm{~cd}$ & $52.0 \pm 3.73 \mathrm{ab}$ & $1.32 \pm 0.19 \mathrm{bc}$ & $0.35 \pm 0.04 \mathrm{~b}$ \\
Sju & $14.6 \pm 1.52 \mathrm{bc}$ & $0.34 \pm 0.01 \mathrm{bc}$ & $43.3 \pm 8.84 \mathrm{a}$ & $0.65 \pm 0.04 \mathrm{ab}$ & $0.48 \pm 0.13 \mathrm{~b}$ \\
Mco & $4.92 \pm 1.04 \mathrm{~d}$ & $0.06 \pm 0.01 \mathrm{e}$ & $86.4 \pm 9.85 \mathrm{~b}$ & $1.88 \pm 0.27 \mathrm{c}$ & $0.10 \pm 0.04 \mathrm{~b}$ \\
Ple & $22.3 \pm 0.47 \mathrm{a}$ & $0.54 \pm 0.01 \mathrm{a}$ & $41.4 \pm 2.11 \mathrm{a}$ & $0.43 \pm 0.03 \mathrm{a}$ & $1.65 \pm 0.35 \mathrm{a}$ \\
Rof & $17.2 \pm 2.26 \mathrm{ab}$ & $0.21 \pm 0.03 \mathrm{~d}$ & $71.6 \pm 9.13 \mathrm{ab}$ & $0.39 \pm 0.16 \mathrm{a}$ & $0.82 \pm 0.24 \mathrm{~b}$ \\
Upa & $8.03 \pm 1.03 \mathrm{~cd}$ & $0.16 \pm 0.05 \mathrm{de}$ & $59.3 \pm 16.7 \mathrm{ab}$ & $0.55 \pm 0.11 \mathrm{ab}$ & $0.58 \pm 0.21 \mathrm{~b}$ \\
$P$ values & $<0.001$ & $<0.001$ & $<0.001$ & $<0.001$ & $<0.01$
\end{tabular}

Species code as in Table 1. A total of 4-6 seedlings per species were considered for all the variables. Different letters indicate significant differences between species (ANOVA, Tukey test, $P<0.05$ ) 
Fig. 2 Relationships between physiological characteristics for the seven considered species. a Relationship between leaf photosynthesis $(A)$ and specific root hydraulic conductance $\left(K_{\mathrm{As}}\right)$. b Relationship between stomatal conductance $\left(g_{\mathrm{s}}\right)$ and $K_{\mathrm{As}}$. c Relationship between $A$ and root hydraulic conductance per root length $\left(K_{\mathrm{RRL}}\right)$. d Relationship between $g_{\text {s }}$ and $K_{\mathrm{RRL}}$. Each value represents the mean. Bars indicate \pm SE $(n=4-6)$. Species code as in Table 1. Cross-species and PIC correlations are shown in Table 3
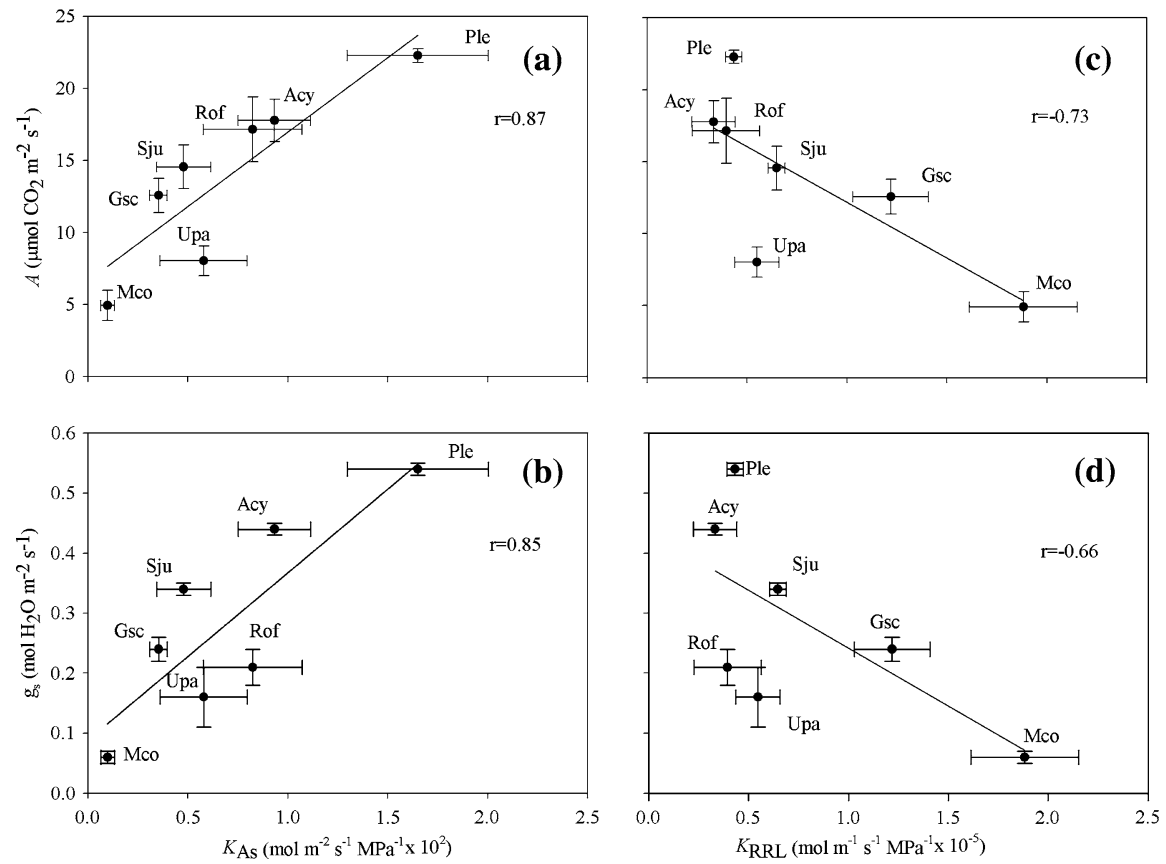

allocation to roots (RMF), since these species have to sustain regrowth after a disturbance (Ackerly 2004; Pausas et al. 2004; Schwilk and Ackerly 2005). G. scorpius, S. junceum, and $U$. parviflorus differed from the other species in stem and leaf parameters. These three species allocated a high proportion of biomass to stem and a low proportion to leaves. All three species have green stems, which have been considered as an advantageous trait in arid habitats with high irradiance regimes (Valladares et al. 2003).

The root morphology and distribution is related to the ability of plants to access water and nutrients (Steudle 2000; Green et al. 2005). In our study, morphological traits related to the structure of the root system showed a significant correlation with plant functional traits. This is in agreement with many studies evidencing the close relationship between root system development and aboveground physiological responses (Norby et al. 2001; Filella and Peñuelas 2003; Trubat et al. 2006; Chirino et al. 2008). Root structure, root soil colonization, and root:shoot ratio are important for evaluating hydraulic limits in the soil-leaf continuum (Davis et al. 1998; Sperry et al. 2002), and thus play an important role in the species' performance.

Specific root length (SRL) is a trait that characterizes the economical aspects of the root system construction costs and it has been related to root's efficiency to soil exploration and to water and nutrient acquisition, since it indicates the amount of root length achieved per unit root mass invested (Lambers et al. 2006; Ostonen et al. 2007). The positive correlation found between SRL and the root length to total plant biomass ratio (RL/B) (Fig. 1; Table 3) suggests that differences in SRL are associated with the root system extension. M. communis was the species with the lowest SRL and RL/B but with the highest root:shoot ratio in agreement with its high RMF, indicating high root construction costs by this species. High root:shoot ratios and low SRL values for M. communis have also been reported in field conditions (Silva et al. 2002).

$G$. scorpius, $R$. officinalis, and $U$. parviflorus showed significantly higher root-to-photosynthetic area ratio $\left(A_{\mathrm{R}}: A_{\mathrm{P}}\right)$ values than $M$. communis. This parameter is related to plant hydraulic architecture, associated to the amount of water that can be extracted from the soil and transported to leaves (Addington et al. 2006). A high $A_{\mathrm{R}}: A_{\mathrm{P}}$ favors the ability to extract water from soil by increasing the surface in contact with soil to better supply to the photosynthetic organs (Ewers et al. 2000; Hacke et al. 2000). This structural trait could be related to the higher drought tolerance reported in post-fire seeders 


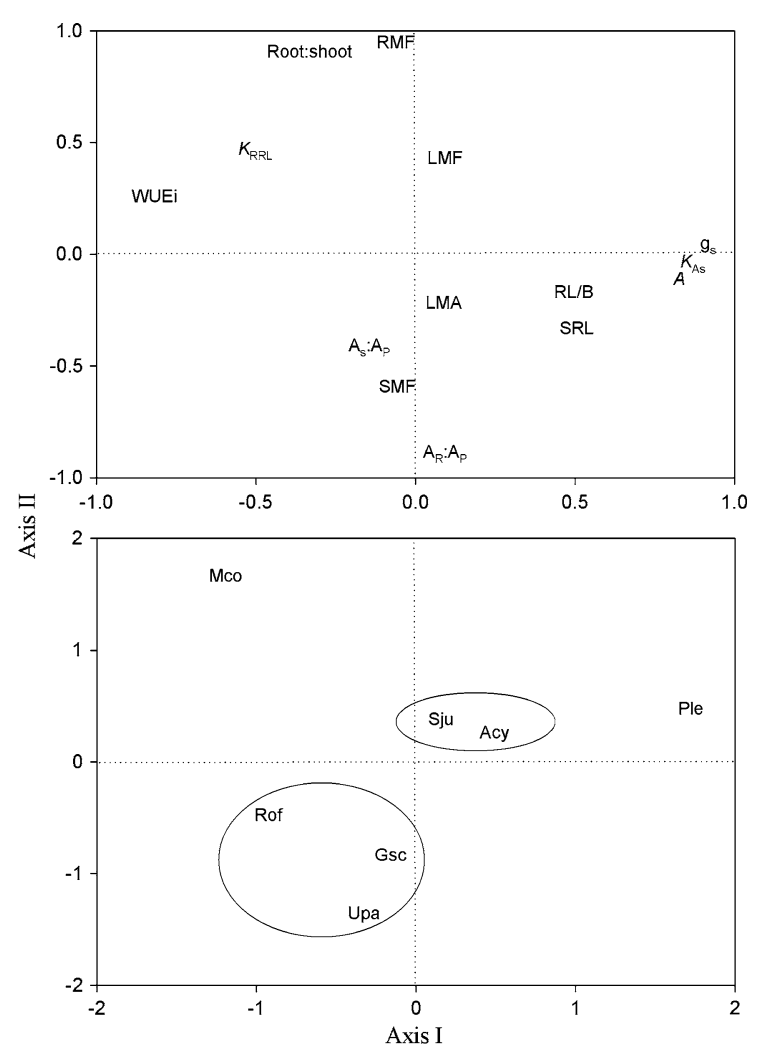

Fig. 3 Distribution of traits (upper panel) and the studied species (lower panel) as a function of principal components 1 and 2 resulting from multivariate analysis among the morphological (RMF, SMF, LMF, root:shoot ratio, SRL, RL/B, LMA, $A_{\mathrm{s}}: A_{\mathrm{P}}$, and $A_{\mathrm{R}}: A_{\mathrm{P}}$; variables code as in Table 2) and physiological traits included in the study $\left(A, g_{\mathrm{s}}\right.$, WUEi, $K_{\mathrm{As}}, K_{\mathrm{RRL}}$; variables code as in Table 4). Species code as in Table 1

species (Paula and Pausas 2006; Pratt et al. 2007). In contrast, M. communis showed the lowest $A_{\mathrm{R}}: A_{\mathrm{P}}$ value, which could limit its water extraction potential under drought conditions.

Relationship between root morphology and plant physiology

Specific root length and RL/B were positively correlated with the net $\mathrm{CO}_{2}$ assimilation rate $(A)$ and negatively correlated with the root hydraulic conductance per root length $\left(K_{\mathrm{RRL}}\right)$ across all the species studied. The species with thinner roots (i.e., high SRL) showed a low $K_{\mathrm{RRL}}$ but a high capacity for soil exploration with high specific hydraulic conductance $\left(K_{\text {As }}\right)$. These patterns suggest that both leaf gas exchange and plant hydraulic capacity are determined by the root system morphology. A higher SRL has been associated with a higher nitrogen absorption rate, which, in turn, is correlated with plant functional responses as increases in maximum relative growth rate (Osone and Tateno 2005). The positive correlation between SRL and $K_{\mathrm{As}}$ indicates that the root systems characterized by less massive roots per unit length have a higher hydraulic conductance. Previous significant correlations between root morphology parameters as SRL and hydraulic conductivity in herbaceous and woody species have also been reported (Rieger and Litvin 1999; Pemán et al. 2006), highlighting the role of root architecture in plant water status. Indeed, root structure has been related to the variability in physiological traits, including the vulnerability to cavitation in Mediterranean shrubs of California (Jacobsen et al. 2005, 2007a).

M. communis was the species that displayed the lowest SRL, $K_{\mathrm{As}}$, and stomatal conductance $\left(g_{\mathrm{s}}\right)$ values but the highest $K_{\mathrm{RRL}}$. Rieger and Litvin (1999) also reported low SRL associated to high $K_{\mathrm{RRL}}$ values, suggesting a strong role for the radial path length in the root system hydraulic conductivity. Leaf gas exchange variables ( $A$ and $g_{\mathrm{s}}$ ) were positively correlated with $K_{\mathrm{As}}$ across the species (Fig. 2; Table 3). Species with greater $K_{\mathrm{As}}$ displayed greater leaf gas exchange values consistent with previously reported correlations (Bond and Kavanagh 1999; Sperry et al. 2002; Hernández et al. 2009). High photosynthetic rates and the correspondingly high stomatal conductance must be supported by high hydraulic conductance (Mencuccini and Comstock 1999; Hubbard et al. 2001; Sellin and Kupper 2007). Under optimal soil water supply, high $K_{\mathrm{As}}$ allows more efficient water transport from stems into photosynthetic organs to compensate leaf water loss and consequently maintain daily water potential high (Ackerly 2004; Jacobsen et al. 2007b). However, in this study there was no significant correlation among sapwood area: photosynthetic area ratio $\left(A_{\mathrm{S}}: A_{\mathrm{P}}\right)$ and $K_{\text {As. }}$. These results suggest that changes in xylem anatomy (i.e., vessel size and density) among species could be related to plant functional strategies. Previous studies have suggested that there may be a range of ecologically significant vessel strategies available to species (Ackerly 2004; Preston et al. 2006; Jacobsen et al. 2007b).

Among these species, there was variability in leaf WUEi, but probably the differences in leaf WUEi are 
more noticeable when species are under stronger water stress conditions (Medrano et al. 2009). In any case, $M$. communis and $P$. lentiscus were the species that showed the most contrasted water use strategies, with a significantly higher WUEi in $M$. communis. Leaf WUEi showed a negative trend respect to SRL, since plants with a high WUEi presented lower SRL values. In this regard, Jacobsen et al. (2008) suggested that different water-use strategies highlight the importance of root structure and function among Mediterranean species. The high WUEi at leaf level in $M$. communis under watered conditions could be due to its low capacity to transport water to leaves together with its low stomatal density (Medrano et al. 2009) and therefore, low stomatal conductance. In contrast, $P$. lentiscus showed low WUEi but high $K_{\mathrm{As}}$ and $g_{\mathrm{s}}$ values. Additionally, the high stomatal conductance measured in P. lentiscus could also be related to its high stomatal density compared with other species (Galmés et al. 2007).

Multivariate analysis: morphological, physiological traits and interspecific variability

The principal components analysis (PCA) including all the characters measured reflected the existence of specific differences in morphological and physiological traits among the seven species studied (Fig. 3). The main variation trend, marked by the PCA axis I, underlined the link between the physiological water use variables, evidenced by the association of $K_{\mathrm{As}}$ and gas exchange variables ( $A$ and $g_{s}$ ). Indeed, a trade-off was detected between $A, g_{\mathrm{s}}, K_{\mathrm{As}}$, and WUEi, reflecting the contrasted strategies of $P$. lentiscus and $M$. communis. The PCA evidenced a net separation between P. lentiscus and $M$. communis, in spite of having very similar life form (broad-leaved evergreen resprouting shrubs). The high WUEi associated with M. communis could offset the low gas-exchange rates. In contrast, $P$. lentiscus showed low WUEi respect to the rest of the species due to its high stomatal conductance rates under a favorable plant water status. However, high values of WUEi in $P$. lentiscus have been reported in field-grown under drought conditions (Flexas et al. 2001).

The second component was related to morphological traits, reflecting a strong negative relationship between root allocation (root:shoot, RMF) and $A_{\mathrm{R}}: A_{\mathrm{P}}$. The PCA displayed an association between species, underlining the high similarity on the one hand of $A$. cytisoides and $S$. junceum, and on the other hand of $G$. scorpius and $U$. parviflorus respect to morphological and physiological traits. $R$. officinalis was closer to $G$. scorpius and $U$. parviflorus than to the other species. These species showed high ratio $A_{\mathrm{R}}: A_{\mathrm{P}}$ but low root allocation, which could be related with the high drought tolerance exhibited by these species in Mediterranean ecosystems (Valladares et al. 2003; Paula and Pausas 2006).

In summary, the different physiological behavior found in the seedlings of seven Mediterranean species appears to be related mainly to their architectural traits. These results highlight the role of root traits, such as SRL and plant hydraulic capacity, as important determinants of interspecific differences in leaf responsiveness in Mediterranean species. Most significant cross-species correlations were supported by significant phylogenetically independent contrasts, suggesting a lack of evolutionary associations between the traits measured across species. Therefore, the different species strategies observed in this study with regard to morphological and physiological traits are indicative of the great diversity of mechanisms that allow Mediterranean plants with similar and different life forms to persist and coexist in water-limited environments.

Acknowledgments This work has been financed by the Spanish projects SINREG (REN2003-07198-C02-02/GLO), PERSIST (CGL2006-07126/BOS), ESTRES (063/SGTB/ 2007/7.1) and Consolider-Ingenio (GRACCIE CSD200700067). E.I. Hernández thanks the University of Alicante for her FPU research fellowship. A. Vilagrosa thanks the GV for his post-doctoral grant (BEST08/017). We are all grateful to S. Paula, M. Llorca, B. Moreira and V.C. Luis for their assistance in the experiment, and to the Banc de Llavors Forestals of the Generalitat Valenciana for access to material and installations. Also thanks to J. Scheiding for the language corrections on the manuscript and two anonymous reviewers for their valuable comments and suggestions. CEAM is supported by the Generalitat Valenciana and Bancaixa.

\section{References}

Ackerly D (2004) Functional strategies of chaparral shrubs in relation to seasonal water deficit and disturbance. Ecol Monogr 74:25-44 
Addington RN, Donovan LA, Mitchell RJ, Vose JM, Pecot SD, Jack SB, Hacke UG, Sperry JS, Oren R (2006) Adjustments in hydraulic architecture of Pinus palustris to maintain similar stomatal conductance in xeric and mesic habitats. Plant Cell Environ 29:535-545

Bell DT (2001) Ecological response syndromes in the flora of southwestern Western Australia: fire resprouters versus reseeders. Bot Rev 67:417-440

Bond BJ, Kavanagh KL (1999) Stomatal behaviour of four woody species in relation to leaf-specific hydraulic conductance and threshold water potential. Tree Physiol 19:503-510

Brodribb TJ, Feild TS (2000) Stem hydraulic supply is linked to leaf photosynthetic capacity: evidence from New Caledonian and Tasmanian rainforests. Plant Cell Environ 23:1381-1388

Canadell J, Zedler PH (1995) Underground structures of woody plants in Mediterranean ecosystems of Australia, California and Chile. In: Fox M, Kalin M, Zedler PH (eds) Ecology and biography of Mediterranean ecosystems in Chile, California and Australia. Berlin, Springer-Verlag, pp 177-210

Chirino E, Vilagrosa A, Hernández EI, Matos A, Vallejo VR (2008) Effects of a deep container on morpho-functional characteristics and root colonization in Quercus suber L. seedlings for reforestation in Mediterranean climate. For Ecol Manag 256:779-785

Clemente AS, Rego FC, Correoa OA (2005) Growth, water relations and photosynthesis of seedlings and resprouts after fire. Acta Oecol 27:233-243

Cochard H, Rodolphe M, Gross P, Bogeat-Triboulot MB (2000) Temperature effects on hydraulic conductance and water relations of Quercus robur L. J Exp Bot 51:12551259

Davis SD, Kolb KJ, Barton KP (1998) Ecophysiological processes and demographic patterns in the structuring of California chaparral. In: Rundel PW, Montenegro G, Jaksic FM (eds) Landscape disturbance and biodiversity in Mediterranean-type ecosystems. Springer-Verlag, Berlin, Heildelberg, pp 297-310

Davis SD, Ewers FW, Wood J, Reeves JJ, Kolb KJ (1999) Differential susceptibility to xylem cavitation among three pairs of Ceanothus species in the transverse mountain ranges of southern California. Ecoscience 6:180-186

Ewers BE, Oren R, Sperry JS (2000) Influence of nutrient versus water supply on hydraulic architecture and water balance in Pinus taeda. Plant Cell Environ 23:1055-1066

Felsenstein J (1985) Phylogenies and the comparative method. Am Nat 125:1-15

Filella I, Peñuelas J (2003) Partitioning of water and nitrogen in co-ocurring Mediterranean woody shrub species of different evolutionary history. Oecologia 137:51-61

Fleck I, Diaz C, Pascual M, Iniguez FJ (1995) Ecophysiological differences between first-year resprouts after wildfire and unburned vegetation of Arbutus unedo and Coriaria myrtifolia. Acta Oecol 16:55-56

Fleck I, Hogan KP, Llorens L, Abadía A, Aranda X (1998) Photosynthesis and photoprotection in Quercus ilex resprouts after fire. Tree Physiol 18:607-614
Flexas J, Gulías J, Jonasson S, Medrano H, Mus M (2001) Seasonal patterns and control of gas exchange in local populations of the Mediterranean evergreen shrub Pistacia lentiscus L. Acta Oecol 22:33-43

Galmés J, Flexas J, Savé R, Medrano H (2007) Water relations and stomatal characteristics of Mediterranean plants with different growth forms and leaf habits: responses to water stress and recovery. Plant Soil 290:139-155

Green JJ, Baddeley JA, Cortina J, Watson CA (2005) Root development in the Mediterranean shrub Pistacia lentiscus as affected by nursery treatments. J Arid Environ $61: 1-12$

Hacke UG, Sperry JS, Pittermann J (2000) Drought experience and cavitation resistance in six shrubs from the Great Basin, Utah. Basic Appl Ecol 1:31-41

Hernández EI, Vilagrosa A, Luis VC, Llorca M, Chirino E, Vallejo VR (2009) Root hydraulic conductance, gas exchange and leaf water potential in seedlings of Pistacia lentiscus L. and Quercus suber L. grown under different conditions of fertilization and light regimes. Environ Exp Bot 67:269-276

Huang B, Eissenstat DM (2000) Linking hydraulic conductivity to anatomy in plants that vary in specific root length. J Am Soc Hortic Sci 125:260-264

Hubbard RM, Ryan MG, Stiller VS, Sperry JS (2001) Stomatal conductance and photosynthesis vary linearly with plant hydraulic conductance in ponderosa pine. Plant Cell Environ 24:113-121

Jacobsen AL, Ewers FW, Pratt RB, Paddock WA III, Davis SD (2005) Do xylem fibers affect vessel cavitation resistance? Plant Physiol 139:546-556

Jacobsen AL, Agenbag L, Esler KJ, Pratt RB, Ewers FW, Davis SD (2007a) Xylem density, biomechanics and anatomical traits correlate with water stress in 17 evergreen shrub species of the Mediterranean-type climate region of South Africa. J Ecol 95:171-183

Jacobsen AL, Pratt RB, Ewers FW, Davis SD (2007b) Cavitation resistance among 26 chaparral species of southern California. Ecol Monogr 77:99-115

Jacobsen AL, Pratt RB, Davis SD, Ewers FW (2008) Comparative community physiology: nonconvergence in water relations among three semi-arid shrub communities. New Phytol 180:100-113

Keeley JE (1998) Coupling demography, physiology and evolution in chaparral shrubs. In: Rundel PW, Montenegro G, Jaksic FM (eds) Landscape disturbance and biodiversity in Mediterranean-type ecosystems. SpringerVerlag, New York, pp 257-264

Keeley JE, Baer-Keeley M, Fotheringham CJ (2005) Alien plant dynamics following fire in Mediterranean-climate California shrublands. Ecol Appl 15:2109-2125

Kummerow J (1981) Structure of roots and root systems. In: Di Castri F, Goodall DW, Specht RL (eds) Mediterraneantype shrublands. Elsevier, Amsterdam, The Netherlands, pp 269-288

Lambers H, Shane MW, Cramer MD, Pearse SJ, Veneklaas EJ (2006) Root structure and functioning for efficient acquisition of phosphorus: matching morphological and physiological traits. Ann Bot 98:693-713 
Levin DA, Schmidt KP (1985) Dynamics of a hybrid zone in Phlox: an experimental demographic investigation. Am J Bot 72:1404-1409

Levitt J (1980) Responses of plants to environmental stress, 2nd edn. Academic Press, USA, p 454

Lo Gullo MA, Salleo S (1988) Different strategies of drought resistance in three Mediterranean sclerophyllous trees growing in the same environmental conditions. New Phytol 108:267-276

Martínez-Vilalta J, Piñol J, Beven K (2002) A hydraulic model to predict drought-induced mortality in woody plants: an application to climate change in the Mediterranean. Ecological Modelling 155:127-147

Medrano H, Flexas J, Galmés J (2009) Variability in water use efficiency at the leaf level among Mediterranean plants with different growth forms. Plant Soil 317:17-29

Mencuccini M, Comstock J (1999) Variability in hydraulic architecture and gas exchange of common bean (Phaseolus vulgaris) cultivars under well-watered conditions: interactions with leaf size. Funct Plant Biol 26:115-124

Mitchell PJ, Veneklass EJ, Lambers H, Burgess SSO (2008) Leaf water relations during summer water deficit: differential responses in turgor maintenance and variation in leaf structure among different plant communities in southwestern Australia. Plant Cell Environ 31:1791-1802

Nardini A, Salleo S (2000) Limitation of stomatal conductance by hydraulic traits: sensing or preventing xylem cavitation? Trees 15:14-24

Norby RJ, Ogle K, Curtis PS, Badeck FW, Huth A, Hurtt GC, Kohyama T, Peñuelas J (2001) Aboveground growth and competition in forest gap models: an analysis for studies of climatic change. Clim Chang 51:415-447

Ojeda F, Brun FG, Vergara JJ (2005) Fire, rain and the selection of seeder and resprouter life-histories in firerecruiting, woody plants. New Phytol 168:155-165

Osone Y, Tateno M (2005) Applicability and limitations of optimal biomass allocation models: a test of two species from fertile and infertile habitats. Ann Bot 95:1211-1220

Ostonen I, Püttsepp Ü, Biel C, Alberton O, Bakker MR, Löhmus K, Majdi H, Metcalfe D, Olsthoorn AFM, Pronk A, Vanguelova E, Weih M, Brunner I (2007) Specific root length as an indicator of environmental change. Plant Biosyst 141:426-442

Pardo C, Cubas P, Tahiri H (2004) Molecular phylogeny and systematics of Genista (Leguminosae) and related genera based on nucleotide sequences of nrDNA (ITS region) and cpDNA (trn L- trn F intergenic spacer). Plant Syst Evol 244:93-119

Paula S, Pausas JG (2006) Leaf traits and resprouting ability in the Mediterranean basin. Funct Ecol 20:941-947

Pausas JG (2004) Changes in fire and climate in the Eastern Iberian Peninsula (Mediterranean Basin). Clim Chang 63:337-350

Pausas JG, Bradstock RA, Keith DA, Keeley JE, The GCTE (Global Change of Terrestrial Ecosystems) Fire Network (2004) Plant functional traits in relation to fire in crownfire ecosystems. Ecology 85:1085-1100

Pemán J, Voltas J, Gil-Pelegrin E (2006) Morphological and functional variability in the root system of Quercus ilex L. subject to confinement: consequences for afforestation. Ann For Sci 63:425-430
Pou A, Flexas J, Alsina MDM, Bota J, Carambula C, De Herralde F, Galmés J, Lovisolo C, Jiménez M, RibasCarbó M, Rusjan D, Secchi F, Tomàs M, Zsófi Z, Medrano H (2008) Adjustments of water use efficiency by stomatal regulation during drought and recovery in the drought-adapted Vitis hybrid Richter-110 (V. berlandieri $\times$ V. rupestris). Physiol Plant 134:313-323

Pratt RB, Jacobsen AL, Golgotiu KA, Sperry JS, Ewers FW, Davis SD (2007) Life history type and water stress tolerance in nine California chaparral species (Rhamnaceae). Ecol Monogr 77:239-253

Preston KA, Cornwell WK, DeNoyer JL (2006) Wood density and vessel traits as distinct correlates of ecological strategy in 51 California coast range angiosperms. New Phytol 170:807-818

Rieger M, Litvin P (1999) Root system hydraulic conductivity in species with contrasting root anatomy. J Exp Bot 50:201-209

Schwilk DW, Ackerly DD (2005) Limiting similarity and functional diversity along environmental gradients. Ecol Lett 8:272-281

Sellin A, Kupper P (2007) Effects of enhanced hydraulic supply for foliage on stomatal responses in little-leaf linden (Tilia cordata Mill.). Eur J Forest Res 126:241-251

Silva JS, Rego FC, Martins-Louçsão MA (2002) Belowground traits of mediterranean woody plants in a portuguese shrubland. Ecol Mediterr 28:5-13

Specht RL (1987) The effect of summer drought on vegetation structure in the Mediterranean climate region of Australia. In: Tenhunen JD, Catarino FM, Lange OL, Oechel WC (eds) Plant response to stress: functional analysis in Mediterranean ecosystems, NATO ASI Series. SpringerVerlag, Berlin, pp 625-640

Sperry JS, Hacke UG, Oren R, Comstock JP (2002) Water deficits and hydraulic limits to leaf water supply. Plant Cell Environ 25:251-263

Steudle E (2000) Water uptake by roots: effects of water deficit. J Exp Bot 51:1531-1542

Trubat R, Cortina J, Vilagrosa A (2006) Plant morphology and root hydraulics are altered by nutrient deficiency in Pistacia lentiscus. Trees 29:2153-2167

Tyree MT, Davis SD, Cochard H (1994) Biophysical perspectives of xylem evolution: is there a tradeoff of hydraulic efficiency for vulnerability to disfunction? IAWA J 15:335-360

Tyree MT, Patiño S, Bennink J, Alexander J (1995) Dynamic measurements of root hydraulic conductance using a highpressure flowmeter in the laboratory and field. J Exp Bot 46:83-94

Tyree MT, Velez V, Dalling JW (1998) Growth dynamics of root and shoot hydraulic conductance in seedlings of five neotropical tree species: scaling to show possible adaptation to differing light regimes. Oecologia 114:93-298

Valladares F, Hernández LG, Dobarro I, García-Pérez C, Sanz R, Pugnaire FI (2003) The ratio of leaf to total photosynthetic area influences shade survival and plastic response to light of green-stemmed leguminous shrub seedlings. Ann Bot 91:577-584

Valladares F, Vilagrosa A, Peñuelas J, Ogaya R, Camarero JJ, Corchera L, Sisó S, Gil-Pelegrín E (2008) Estrés hídrico: ecofisiología y escalas de sequía. In: Valladares F (ed) 
Ecología del bosque mediterráneo en un mundo cambiante, 2nd edn. Organismo Autónomo de Parques Nacionales. Ministerio de Medio Ambiente, Madrid, Spain, pp 163-190

Vallejo VR, Bautista S, Cortina J (1999) Restoration for soil protection after disturbances. In: Trabaud L (ed) Life and environment in the Mediterranean. Southampton, WIT Press, pp 301-344

Verdaguer D, Ojeda F (2002) Root starch storage and allocation patterns in seeder and resprouter seedlings of two Cape Erica (Ericaceae) species. Am J Bot 89:1189-1196
Vilagrosa A, Bellot J, Vallejo VR, Gil-Pelegrín E (2003) Cavitation, stomatal conductance, and leaf dieback in seedlings of two co-occurring Mediterranean shrubs during an intense drought. J Exp Bot 54:2015-2024

Webb CO, Ackerly DD, Kembel SW (2008) Phylocom: software for the analysis of phylogenetic community structure and trait evolution. Bioinformatics 24:2098-2100 